\title{
A DREEM Based Appraisal of Educational Environment at Dental Colleges: Comparing Pakistan and Turkey
}

\author{
Ayesha Zafar ${ }^{1}$ \\ BDS \\ Shama Asghar ${ }^{2}$ \\ BDS, FCPS \\ Muhammad Faisal Fahim ${ }^{3}$ \\ MSc
}

OBJECTIVE: This study was conducted to establish a baseline DREEM score for a Pakistani private dental college and a private dental college of Turkey, to compare the educational environment as perceived by the dental students' of the two institutes and provide insight into the aspects of dental education that are in need of improvement.

METHODOLOGY: It's a cross- sectional, questionnaire based study conducted at Bahria University Medical and Dental College, Karachi (BUMDC) and a private dental college of Istanbul, Turkey between December 2018 and March 2019. The Dundee Ready Education Environment Measure was filled out by first, second and third year undergraduate dental students at both the institutes. Ethical approval was obtained from ethical review committee of BUMDC after consent was taken from the head of the Turkish institute.

RESULTS: Global DREEM mean score of the two institutes was $116.6 \pm 20.7$. The overall DREEM score of Bahria University was $119.3 \pm 24.3$ while of Turkish dental institute was $113.8 \pm .16 .1$, with p-value $=0.000$. Institutional DREEM depicts a student perception that is predominantly positive. In both the institutes, the perception regarding the social atmosphere (Students' Social Self Perception) scored lowest as compared to all other domains.

CONCLUSION: Over all the educational environment at both the institutes is satisfactory however this study has highlighted a need for reforms to improve the social and teaching atmosphere. Despite the overall positive trend, the institutes have yet to achieve excellent status for educational environment. One can learn from the Turkish university in terms of how the social atmosphere can be improved, while the Turkish dental college can benefit by implementing a more student centered teaching methodology.

KEYWORDS: DREEM, Educational environment, dental students, perception, Pakistan.

HOW TO CITE: Zafar A, Asghar S, Fahim MF. A DREEM based appraisal of educational environment at dental colleges: comparing Pakistan and Turkey. J Pak Dent Assoc 2020;29(3):135-139.

DOI: https://doi.org/10.25301/JPDA.293.135

Received: 02 November 2019, Accepted: 11 May 2020

\section{INTRODUCTION}

$\mathrm{D}$ efined as everything that is part of the academic institute and affects the learning process, educational environment includes infrastructure, teaching methodology, attitude and behaviour of both teachers and peers. ${ }^{1,2,3}$ Numerous studies have proven that educational environment is a major determinant of successful learning instruction. ${ }^{4,5,6}$ The atmosphere of an institute is considered a stronger predictor of academic growth as compared to prior achievement at school. ${ }^{3}$ It bears considerable consequence on the effectiveness of curriculum and hence

1. Registrar, Department of Operative Dentistry, Bahria University Medical and Dental College, Karachi.

2. Associate Professor, Department of Operative Dentistry, Bahria University Medical and Dental College, Karachi

3. Reseacher, Department of Physiotherapy, Bahria University Medical and Dental College, Karachi

Corresponding author: "Dr. Ayesha Zafa” < ayeshazaf19@gmail.com > skill, motivation and eventual success of the student. ${ }^{7}$ The acute noteworthiness of this arbitrary component of medical and dental education brought about the need to qualitatively measure it with a reproducible, universally accepted technique. $^{8}$

Advances in this front led to the development of Dundee Ready Educational Environment Measure (DREEM) questionnaire by a multinational committee of medical educators in 1997. ${ }^{19,10}$ Further research has established it as a globally recognized and validated tool for "measuring' the perception of learning environment of students at medical and dental institutes. ${ }^{11,12}$ Culturally nonspecific, it is an inventory of fifty components that focus on five domains of education namely learning, teaching, academic and social self-perception \& atmosphere. ${ }^{13}$ It draws a holistic and comprehensive snapshot of all the domains at work within the educational institute. ${ }^{14} \mathrm{~A}$ considerable impact of this inventory is that it makes homogenized comparisons between 
medical and dental schools of different countries, a possibility, allowing institutes to establish a point of reference for future comparisons. ${ }^{15,16,17}$ Moreover, it may bring to light areas of concerns that might have been unintentionally left out by the educators. ${ }^{18,19}$

Bahria University Medical and Dental College (BUMDC), is located in the metropolis of Karachi. Established in 2011, the dental college follows a hybridmodular curriculum and incorporates both traditional and latest student based teaching methodology. With a teaching history of less than a decade the college is still in its infancy and hence in constant need of rigorous introspection in order to optimize the learning environment. ${ }^{20}$

Despite its validity as a successful investigative tool for evaluation of quality of teaching, only a handful of DREEM based researches have been conducted in dental colleges of Pakistan and not one international comparison has been made thus far. ${ }^{10}$

This study was conducted to establish a baseline DREEM score, to juxtapose the educational environment perception of student of the two institutes and provide insight into the aspects of dental education that are in need of improvement.

\section{METHODOLOGY}

Permission for the research was granted by the Ethical review committee of BUMDC (ERC 05/2019). It was a cross-sectional questionnaire based survey. Students who had completed one, two or three years of undergraduate dental education at Bahria University Medical and Dental College, Karachi and a private dental college located in Istanbul, Turkey were invited to take part in it between the period of December 2018 and March 2019. Final year students and house officers were excluded from the study. Sample size of 132 students from each institute was calculated, keeping the confidence interval at $95 \%$, margin of error at $0.5 \%$, population size of 200 and prevalence of $50 \%$. Formula used was,

Sample size $n=[D E F F * N p(1-p)] /[(d 2 / Z 21-\alpha / 2 *(N-1)+p *(1-p)]$

Convenience sampling technique was used. In all, 264 participants were requested to take part in the study. Participation in the study was voluntary. Data from the Turkish private dental college was collected by a faculty member who was selected under Erasmus teaching mobility program from Bahria University to deliver a lecture to dental students of the Turkish dental college. After the lecture, faculty member explicated the purpose and idea of the study, assured confidentiality and took assent before asking the students to fill the proforma. The original English DREEM inventory was translated into Turkish. Validity of the translation was evaluated with a pilot study and the participants of the pilot study were then excluded from the final study. Similarly at our institute, after explaining the purpose of the study and taking consent, 132 original English language DREEM forms were circulated. Anonymity of the process was reassured. A total of 121 students responded from Bahria University and 124 responded from the Turkish dental college.

The DREEM questionnaire was employed to measure educational environment's perception of the participants. Based on five main domains and a total score of 200, it comprises of a 50-item inventory focused on statements related to the Educational Environment namely Students' perceptions of learning (SPL) with 12 statements and a total sum of 48, Students' perceptions of teachers (SPT) having 11 articles and topmost sum of 44, Students' academic selfperceptions (SASP) with total of 8 statements and a total sum of 32, Students' perceptions of atmosphere (SPA) comprising of 12 articles and an absolute sum of 48 and lastly Students' social self-perceptions (SSSP) with 7 statements and topmost sum of 28.

5- point Likert type scale was employed to collect responses ranging from strongly agree (4) to strongly disagree (0). The nine negative statements were tallied in reverse manner where strongly agree was scored 0 and strongly disagree scored 4. Incomplete questionnaires were excluded from the study. As suggested by McAleer and Roff in their DREEM inventory guide, the total DREEM score was interpreted as follows: total score of 0-50 was considered very poor, 51-100 as an environment with plenty of problems, score between 101-150 was considered more positive than negative, 151-200 as excellent. Individual statement scores $\leq 3.5$ was considered real positive, a score of 2.0-3.0 suggested that the item has room for improvement and an average score of $\leq 2.0$ was considered troublesome.

The data was compiled manually into MS Office Excel Version 2010 spread sheets from both the countries and then into SPSS Version 23. For categorical variables such as nationality, frequency and percentages were presented. Continuous variables such as age and DREEM scores were presented as mean \pm standard deviation (SD). To know the significance between Bahria University's and Turkish dental college students with DREEM score independent sample ttest was applied. For comparison of different level of students with their achieved scores of DREEM inventory Fisher exact test was applied. $p$-value of $\leq 0.05$ was considered to be statistically significant.

\section{RESULTS}

Response rate of our institute was $91.6 \%$ while that of 
Turkish University was $93.9 \%$. Average age of the Pakistani students was $20.74 \pm 1.24$ years $(18-26)$ and that of Turkish students was $20.61 \pm 1.92$ years (17-33)

Table 1 mentions the Global DREEM mean score of the two institutes and the combined subscale score. The total DREEM score of our institute was $119.34 \pm 24.26$ while of

Table 1: Overall DREEM score (mean and standard deviation) and total score of DREEM subscales.

(Combined score of Pakistan and Turkey)

\begin{tabular}{|l|c|c|}
\hline & Mean & Std. Deviation \\
\hline Overall sum & 116.56 & 20.69 \\
\hline SPL sum & 28.69 & 6.19 \\
\hline SPT sum & 26.07 & 4.92 \\
\hline SASP & 19.35 & 4.83 \\
\hline SPA & 27.62 & 6.98 \\
\hline SSSP & 14.83 & 3.77 \\
\hline
\end{tabular}

SPL: Students' perception of learning

SPT: Students' perception of teachers

SASP: Student's academic self-perception

SPA: Students' perception of atmosphere

SSSP: Students' social self-perception

Turkish dental college was $113.85 \pm 16.13$. Overall as well as individual institutional DREEM depicts a student perception of more positive than negative (101-150). And the difference between the two institutes is statistically significant, $\mathrm{p}$-value $=0.038$

Subscale mean and standard deviation along with their interpretation for both the institutes is displayed in Table 2 .

The table also indicates the significant differences between the two institutes.

Table 2: Mean Scores and standard deviation of different subscales and their interpretation

\begin{tabular}{|c|c|c|c|}
\hline $\begin{array}{l}\text { Subscales and total } \\
\text { score }\end{array}$ & $\begin{array}{l}\text { Pakistani Students } \\
\text { scores and status }\end{array}$ & $\begin{array}{l}\text { Turkish Students score } \\
\text { and status }\end{array}$ & P-value \\
\hline SPL(48) & $\begin{array}{c}30.40 \pm 7.46 \\
25-36=\text { A more positive } \\
\text { perception }\end{array}$ & $\begin{array}{c}27.02 \pm 4.01 \\
\begin{array}{c}25-36=\text { A more positive } \\
\text { perception }\end{array}\end{array}$ & 0.000 \\
\hline SPT(44) & $\begin{array}{l}27.05 \pm 5.45 \\
\begin{array}{l}23-33=\text { Moving in the } \\
\text { right direction }\end{array}\end{array}$ & $\begin{array}{l}25.12 \pm 4.17 \\
\begin{array}{l}23-33=\text { Moving in the } \\
\text { right direction }\end{array}\end{array}$ & 0.002 \\
\hline SASP(32) & $\begin{array}{c}19.78 \pm 5.24 \\
\begin{array}{c}17-24= \\
\text { on the poelings more }\end{array}\end{array}$ & $\begin{array}{c}18.93 \pm 4.38 \\
\begin{array}{c}17-24=\text { Feelings more } \\
\text { on the positive side }\end{array}\end{array}$ & 0.170 \\
\hline SPA(48) & $\begin{array}{c}26.15 \pm 7.05 \\
25-36=\begin{array}{c}\text { A more positive } \\
\text { attitude }\end{array}\end{array}$ & $\begin{array}{c}29.05 \pm 6.63 \\
25-36=\begin{array}{c}\text { A more positive } \\
\text { attitude }\end{array}\end{array}$ & 0.001 \\
\hline SSSP(28) & $\begin{array}{c}15.96 \pm 4.19 \\
15-21=\text { Not too bad }\end{array}$ & $\begin{array}{c}13.73 \pm 2.92 \\
8-14=\text { Not too nice }\end{array}$ & 0.000 \\
\hline
\end{tabular}

Individual item analysis and comparison of the DREEM inventory is presented in Table 3.
Table 3: Individual item mean scores of DREEM inventory for Pakistan and Turkey, along with their p-value

\begin{tabular}{|c|c|c|c|c|}
\hline & & $\begin{array}{l}\text { Pakistani } \\
\text { students }\end{array}$ & $\begin{array}{l}\text { Turkish } \\
\text { students }\end{array}$ & P-value \\
\hline & & Mean \pm SD & Mean \pm SD & \\
\hline SPL1 & $\begin{array}{l}\text { I am encouraged to participate in } \\
\text { class }\end{array}$ & $2.52 \pm 0.93$ & $2.76 \pm 0.93$ & 0.05 \\
\hline SPL2 & The teaching is often stimulating* & $2.47 \pm 0.86$ & $2.83 \pm 0.86$ & 0.001 \\
\hline SPL3 & The teaching is student-centered ${ }^{*}$ & $2.51 \pm 0.80$ & $2.73 \pm 0.88$ & 0.042 \\
\hline SPL4 & $\begin{array}{l}\text { The teaching is sufficiently } \\
\text { concerned to develop my } \\
\text { competence }{ }^{*}\end{array}$ & $2.26 \pm 0.92$ & $1.40 \pm 0.98$ & 0.000 \\
\hline SPL5 & The teaching is well focused & $2.72 \pm 0.70$ & $2.80 \pm 0.90$ & 0.448 \\
\hline SPL6 & $\begin{array}{l}\text { I feel I am being well prepared for } \\
\text { my profession }\end{array}$ & $2.71 \pm 0.93$ & $2.66 \pm 0.98$ & 0.688 \\
\hline SPL7 & The teaching time is put to good use & $2.63 \pm 0.90$ & $2.51 \pm 1.06$ & 0.342 \\
\hline SPL8 & $\begin{array}{l}\text { The teaching over-emphasizes factual } \\
\text { Learning* }\end{array}$ & $2.31 \pm 0.89$ & $1.48 \pm 1.17$ & 0.000 \\
\hline SPL9 & $\begin{array}{l}\text { I am clear about the learning } \\
\text { objectives of the course* }\end{array}$ & $2.36 \pm 0.97$ & $1.48 \pm 0.93$ & 0.000 \\
\hline SPL10 & $\begin{array}{l}\text { The teaching encourages me to be an } \\
\text { active learner" }\end{array}$ & $2.38 \pm 0.98$ & $2.75 \pm 1.09$ & 0.006 \\
\hline SPL11 & $\begin{array}{l}\text { Long term learning emphasizes over } \\
\text { short term* }\end{array}$ & $2.35 \pm 0.98$ & $2.81 \pm 0.83$ & 0.000 \\
\hline SPL12 & The teaching is too teacher-centered & $2.02 \pm 0.92$ & $1.83 \pm 1.10$ & 0.139 \\
\hline SPT13 & The teachers are knowledgeable* & $2.84 \pm 0.85$ & $3.22 \pm 0.93$ & 0.01 \\
\hline SPT14 & $\begin{array}{l}\text { The teachers are patient with } \\
\text { patients }^{*}\end{array}$ & $2.53 \pm 0.91$ & $2.97 \pm 0.92$ & 0.000 \\
\hline SPT15 & The teachers ridicule the students* & $1.99 \pm 0.97$ & $1.51 \pm 1.16$ & 0.001 \\
\hline SPT16 & The teachers are authoritarian & $2.42 \pm 0.78$ & $2.51 \pm 0.98$ & 0.448 \\
\hline SPT17 & $\begin{array}{l}\text { The teachers have good } \\
\text { communications skills with patients* }\end{array}$ & $2.52 \pm 0.93$ & $1.26 \pm 0.97$ & 0.000 \\
\hline SPT18 & $\begin{array}{l}\text { The teachers are good at providing } \\
\text { feedback to students* }\end{array}$ & $2.35 \pm 0.92$ & $2.76 \pm 1.02$ & 0.001 \\
\hline SPT19 & $\begin{array}{l}\text { The teachers provide constructive } \\
\text { criticism here }^{*}\end{array}$ & $2.28 \pm 0.87$ & $2.64 \pm 1.00$ & 0.003 \\
\hline SPT20 & The teachers give clear examples* & $2.52 \pm 0.95$ & $2.91 \pm 1.01$ & 0.003 \\
\hline SPT21 & The teachers get angry in class* & $2.12 \pm 1.02$ & $1.62 \pm 1.06$ & 0.000 \\
\hline SPT22 & $\begin{array}{l}\text { The teachers are well prepared for } \\
\text { their classes }\end{array}$ & $2.67 \pm 0.86$ & $2.82 \pm 1.00$ & 0.229 \\
\hline SPT23 & $\begin{array}{l}\text { The registrars irritate the course } \\
\text { Organizers }\end{array}$ & $1.84 \pm 0.96$ & $1.75 \pm 1.05$ & 0.473 \\
\hline SASP24 & $\begin{array}{l}\text { Learning strategies which worked } \\
\text { for me before continue to work for } \\
\text { me now* }\end{array}$ & $2.32 \pm 0.83$ & $2.54 \pm 0.87$ & 0.048 \\
\hline SASP25 & $\begin{array}{l}\text { I am confident about my passing this } \\
\text { Year*ki }\end{array}$ & $2.54 \pm 1.04$ & $1.38 \pm 1.22$ & 0.000 \\
\hline SASP26 & $\begin{array}{l}\text { The teaching is sufficiently } \\
\text { concerned } \\
\text { to develop my confidence* }\end{array}$ & $2.23 \pm 0.91$ & $2.57 \pm 1.09$ & 0.009 \\
\hline SASP27 & $\begin{array}{l}\text { Last year's work has been a good } \\
\text { preparation for this year's work }\end{array}$ & $2.28 \pm 0.93$ & $2.54 \pm 1.06$ & 0.052 \\
\hline SASP28 & I am able to memorize all I need & $2.25 \pm 0.97$ & $2.34 \pm 1.09$ & 0.496 \\
\hline SASP29 & $\begin{array}{l}\text { I have learned a lot about empathy in } \\
\text { my profession }\end{array}$ & $2.46 \pm 0.94$ & $2.66 \pm 1.04$ & 0.106 \\
\hline SASP30 & $\begin{array}{l}\text { My problem solving skills are being } \\
\text { well developed here }\end{array}$ & $2.51 \pm 1.14$ & $2.70 \pm 0.97$ & 0.163 \\
\hline SASP31 & $\begin{array}{l}\text { Much of what I have to learn seems } \\
\text { relevant to a career in healthcare }\end{array}$ & 2.630 .91 & $2.69 \pm 0.93$ & 0.629 \\
\hline SPA32 & $\begin{array}{l}\text { The atmosphere is relaxed during the } \\
\text { ward teaching }{ }^{*}\end{array}$ & $2.35 \pm 0.96$ & $2.77 \pm 1.01$ & 0.001 \\
\hline SPA33 & This school is well time-tabled ${ }^{*}$ & $2.54 \pm 1.06$ & $2.07 \pm 1.14$ & 0.001 \\
\hline SPS34 & Cheating is a problem in this school & $1.81 \pm 1.27$ & $2.05 \pm 1.35$ & 0.159 \\
\hline SPA35 & $\begin{array}{l}\text { The atmosphere is relaxed during } \\
\text { Lectures* }\end{array}$ & $2.42 \pm 0.88$ & $2.70 \pm 1.00$ & 0.021 \\
\hline SPS36 & $\begin{array}{l}\text { There are opportunities for me to } \\
\text { develop interpersonal skills }\end{array}$ & $2.46 \pm 0.93$ & $2.68 \pm 1.05$ & 0.081 \\
\hline SPA37 & I feel comfortable in class socially ${ }^{*}$ & $2.35 \pm 1.03$ & $2.77 \pm 1.08$ & 0.002 \\
\hline SPA38 & $\begin{array}{l}\text { The atmosphere is relaxed during } \\
\text { seminars /tutorials }\end{array}$ & $2.45 \pm 1.02$ & $2.60 \pm 0.92$ & 0.23 \\
\hline SPA39 & I find the experience disappointing " & $1.67 \pm 1.12$ & $2.52 \pm 1.17$ & 0.000 \\
\hline SPA40 & I am able to concentrate well & $2.33 \pm 0.91$ & $2.51 \pm 0.89$ & 0.111 \\
\hline SPA41 & $\begin{array}{l}\text { The enjoyment outweighs the stress } \\
\text { of the course* }\end{array}$ & $1.99 \pm 1.07$ & $2.38 \pm 0.97$ & 0.003 \\
\hline SPA42 & $\begin{array}{l}\text { The atmosphere motivates me as a } \\
\text { Learner }\end{array}$ & $2.19 \pm 1.01$ & $2.37 \pm 0.96$ & 0.154 \\
\hline SPA43 & The students irritate the teachers & $1.68 \pm 1.21$ & $1.43 \pm 1.10$ & 0.092 \\
\hline SSSP44 & $\begin{array}{l}\text { There is a good support system for } \\
\text { students who get stressed }\end{array}$ & $1.81 \pm 1.29$ & $1.88 \pm 1.17$ & 0.662 \\
\hline +SSSP45 & I am too tired to enjoy the course $*$ & $2.40 \pm 1.15$ & $2.08 \pm 1.14$ & 0.033 \\
\hline SSSP46 & I am rarely bored on this course & $1.94 \pm 1.18$ & $1.98 \pm 1.00$ & 0.766 \\
\hline SSSP47 & I have good friends in this school & $2.86 \pm 1.14$ & $3.04 \pm 0.97$ & 0.205 \\
\hline SSSP48 & My social life is good* & $2.47 \pm 1.19$ & $1.36 \pm 0.94$ & 0.000 \\
\hline SSSP49 & I seldom feel lonely" & $1.98 \pm 1.27$ & $2.33 \pm 1.30$ & 0.032 \\
\hline SSSP50 & My accommodation is pleasant ${ }^{*}$ & $2.29 \pm 1.15$ & $1.19 \pm 1.20$ & 0.000 \\
\hline
\end{tabular}

Statements showing statistically significant difference are marked with * Negative statements are in bold and italics. Students' with the higher score are in stronger agreement with the statement. 


\section{DISCUSSION}

The study aimed to evaluate what differences, if any, existed between private dental college of Turkey and Pakistan in terms of educational environment as perceived by the students. For this purpose the institutes were evaluated by employing the DREEM questionnaires. It is the first time that such a study is being conducted in either of the institutes. With overall DREEM score of $119.3 \pm 24.3$ for BUMDC and 113.8 \pm .16 .1 for the Turkish Institute there appears very little difference in the overall opinion but nonetheless, the difference is statistically significant, $\mathrm{p}$-value $=0.038$.

Scores in the range of 100 to 150 are considered more positive than negative but with definite room for improvement, as only values above 150 are considered excellent. These values are in concurrence with findings of Khan $\mathrm{K}$ et al ${ }^{19}$, who reported a score of 120 for 4 dental institutes of Rawalpindi, Pakistan and also similar to results reported by Tontus $\mathrm{O}$ et $\mathrm{al}^{21}$ of Turkey who stated DREEM score of 107.15/200 for 11 medical faculties in Turkey. Similar scores have been reported for Saudi Arabia1, $\operatorname{Iran}^{3}$, India ${ }^{23}$ and other countries of this region. In contrast to these, higher scores were reported by Vanghan B et al. (135.37 \pm 19.33$)$ in their study ${ }^{9}$ conducted in University of Melbourne, Australia and by Hongkan $\mathrm{W}$ et $\mathrm{al}^{24}$ from Thailand (131.1 \pm 17.0$)$.

Analysis of the subscales revealed that students of Bahria dental college rated the learning environment as the most positive aspect of their environment, suggesting that the students are generally satisfied with the hybrid curriculum, focused on incorporating student centered practices The most highly rated statements were 'I feel I am being well prepared for my profession' and 'teaching time is put to good use' which depicts that the institute is ensuring students' satisfaction when it comes to their future performance. For the Turkish students, the atmosphere of their institute was most highly rated, showing they found the teaching environment relaxed, stress free and overall joyous. Among the highest rated statements were "the atmosphere is relaxed during lectures" and 'I feel comfortable in class socially'. Both the institutes unanimously declared the social selfperception to be the most neglected category, indicating a need for improvement of effective support system for stressed out individuals.

Analysis of the individual items demonstrated that for the private dental college of Turkey, a shift from teacher centred to student centred approach is needed as the statements pertaining to this this category all unanimously scored less than 2. In this domain BUMDC appears to be on the right track as the students have rated this component to be the highest among all others subscales.
According to our findings Bahria dental college needs to work on improving its control over cheating during examination as its one of the poorly rated items. Concerted efforts also need to be put into making the overall university experience enjoyable for the students as they most strongly agreed to the statement "I find the experience disappointing" This study has provided valuable insight into students' perception of their learning environment and how it compares with another international institute. Secondly, individual items analysis highlighted specific problems and strengths within each of the dental colleges.

One of the inherent limitations of DREEM questionnaire is that it does not give any details about the underlying reasons for the highlighted issue nor does it suggest solutions to the problems. Furthermore the DREEM inventory being a predetermined questionnaire might have left out certain factors that impacted our educational setups. Moreover the sampling techniques employed for this study is voluntary participation and this may have resulted in sampling bias. The self-reporting questionnaire is likely associated with response bias. Since this study only compared two dental colleges and its results cannot be generalized, further studies should be done in future with more number of institutes participating in order to establish a generalized score. Moreover this study can be conducted again, in the same dental college, at a later point in time to determine the effect of any changes that the institutes may have made in their educational environment.

\section{CONCLUSION}

This study has highlighted a number of problems that are in need of attention. Both institutes need to reform their educational environment. Even though the overall scores may be predominantly positive both the institutes have yet to achieve excellent status for all the criteria that constitute an educational environment. Bahria University can learn from the Turkish university in terms of how the social atmosphere can be improved, while the Turkish dental college can benefit by implementing a more student centered teaching methodology. DREEM-based surveys are highly recommended for periodic monitoring of the educational environment.

\section{CONFLICT OF INTEREST}

None

\section{FUNDING DISCLOSURE}

No funds were availed 


\section{REFERENCES}

1. Abdullah H, Altemani AH, Merghani TH. The quality of the educational environment in a medical college in Saudi Arabia. Int J Med Educ. 2017;8:128-32.

https://doi.org/10.5116/ijme.58ce.55d2

2. Condon BP, Worley PS, Condon JR, Prideaux DJ. Student academic per-formance in rural clinical schools: The impact of cohort size and competition. Med Teach. 2017; 39:262-68.

https://doi.org/10.1080/0142159X.2017.1270430

3. Bakhshialiabad H, Bakhshi M, Hassanshahi G. Students' perceptions of the academic learning environment in seven medical sciences courses based on DREEM. Adv Med Educ Pract. 2015:23;6:195-203 https://doi.org/10.2147/AMEP.S60570

4. Enns SC, Perotta B, Paro HB, Gannam S, Peleias M, Mayer FB, et al. Medical Students' Perception of their educational environment and quality of life: is there a positive association? Acad Med. 2016; 91:40917.

https://doi.org/10.1097/ACM.0000000000000952

5. Wasson LT, Cusmano A, Meli L, Louh I, Falzon L, Hampsey M, et al. As-sociation between learning environment interventions and medical student well-being: a systematic review. JAMA. 2016;316:2237-52. https://doi.org/10.1001/jama.2016.17573

6. Wasson LT, Cusmano A, Meli L, Louh I, Falzon L, Hampsey M, et al. As-sociation between learning environment interventions and medical student well-being: a systematic review. JAMA. 2016; 316:2237-52. https://doi.org/10.1001/jama.2016.17573

7. Nithiapinyasakul A, Arora R, Chamnan P. Impact of a 20-year collabora-tive approach to increasing the production of rural doctors in Thailand. Int J Med Educ. 2016;7:414-16.

https://doi.org/10.5116/ijme.582f.4d3b

8. Yi Y, Chongsuvivatwong V, Sriplung H, Rueanarong C. CPIRD: A suc-cessful Thai programme to produce clinically competent medical graduates. F1000Res. 2015;4:158.

https://doi.org/10.12688/f1000research.6638.1

9. Vaughan et al. The DREEM, part 1: measurement of the educational environment in an osteopathy teaching program. BMC Medi Educ 2014;14:99.

https://doi.org/10.1186/1472-6920-14-99

10. Ali K, Raja M, Watson G, Coombes L, Heffernan E. The Dental School Learning Milieu: Students' Perceptions at Five Academic Dental Institutions in Pakistan. J Dent Educ. 2012 A;76:487-94.

11. Pai PG, Menezes V, Srikanth, Subramanian AM, Shenoy JP. Medical stu-dents' perception of their educational environment. J Clin Diagn Res. 2014;8:103-07.

12. Brown T, Williams B, Lynch M: The Australian DREEM: evaluating student perceptions of academic learning environments within eight health science courses. Int J Med Educ 2011, 2:94-101 https://doi.org/10.5116/ijme.4e66.1b37
13. Zafar U, Daud S, Shakoor Q, Chaudhry AM, Naser F, Mushtaq M. Medical students' perception of their learning environment at Lahore medical and dental college Lahore. J Ayub Med Coll Abbottabad. 2017; 29:595-98.

14. Luciani E, Cerritelli F, Waters M, Zegarra-Parodi R: Osteopathic student satisfaction and preparedness to practice: A comparative study. Int J Osteopath Med 2013.

https://doi.org/10.1016/j.ijosm.2013.10.009

15. Lokuhetty M, Warnakulasuriya S, Perera R, De Silva H, Wijesinghe H. Students' perception of the educational environment in a Medical Faculty with an innovative curriculum in Sri Lanka. South-East Asian J Med Educ. 2011;4:9-16.

16. Ostapczuk M, Hugger A, de Bruin J, Ritz-Timme S, Rotthoff T, 2012. DREEM on, dentists! Students' perceptions of the educational environment in German dental school as measured by the Dundee Ready Education Environment Measure. Eur. J. Dent. Educ. 2011;16, 67-77. https://doi.org/10.1111/j.1600-0579.2011.00720.x

17. Schönrock-Adema J, Bouwkamp-Timmer T, van Hell EA, CohenSchotanus J: Key elements in assessing the educational environment: where is the theory? Adv Health Sci Educ 2012;17:727-42. https://doi.org/10.1007/s10459-011-9346-8

18. Foster Page L, Kang M, Anderson V, Thomson W: Appraisal of the Dundee Ready Educational Environment Measure in the New Zealand dental educational environment. Eur J Dent Educ 2012;16:78-85. https://doi.org/10.1111/j.1600-0579.2011.00725.x

19. Khan K, Sohail K, Jamil M, Durrani KO. Determining the Quality of Educational Climate Across Four Undergraduate Dental Colleges In Rawalpindi/Islamabad Using The DREEM Inventory. J Med Sci 2016;24:91-7.

20. Bahria.edu.pk. (2020). Bahria University Medical \& Dental Collegel - Bahria University Official Web Portal. [online] Available at: https://bahria.edu.pk/bumdc/ [Accessed 26 Feb. 2020].

21. Tontus O. DREEM; Dreams of the Educational Environment as Its Effect on Education Result of 11 Medical Faculties of Turkey. J Exp Clin Med 2010;27:104-08.

https://doi.org/10.5835/jecm.oти.27.03.002

22. Al-Saleh S, Al-Madi EM, AlMufleh B, Al-Degheishem AH. Educational environment as perceived by dental students at King Saud University. Saudi Dent J. 2018;30:240-49.

https://doi.org/10.1016/j.sdentj.2018.02.003

23. Patil AA, Chaudhari VL. Students' perception of the educational environment in medical college: a study based on DREEM questionnaire. Korean J Med Educ. 2016; 28:281-88.

https://doi.org/10.3946/kjme.2016.32

24. Hongkan W, Arora R, Muenpa R, Chamnan P. Perception of educational environment among medical students in Thailand. Int $\mathrm{J}$ Med Educ. 2018;9:18-23.

https://doi.org/10.5116/ijme.5a4a.1eda 